\title{
Analisis Gaya Belajar Siswa pada Mata Pelajaran IPS di Kelas VII SMP Negeri 9 Kota Jambi
}

\author{
Diliza Afrila ${ }^{1}$, Abd. Rahman ${ }^{2}$ \\ FKIP Universitas Batanghari Jambi, Program Studi Pendidikan Ekonomi \\ FKIP Universitas Batanghari Jambi, Program Studi Pendidikan Sejarah ${ }^{2}$
}

\begin{abstract}
This study aims to analyze the learning styles of students on the subjects of social studies in class VII SMP Negeri 9 Kota Jambi. The type of this research is descriptive research with quantitative approach. The population in this study is 251 people. Sampling technique in this research is proportional random sampling, so selected 72 students as sample of research. Data collection techniques in this study is to spread the questionnaire to the research respondents. Data analysis technique in this research is descriptive analysis. The results showed that the average of student learning style variables on social studies subjects in class VII of SMP Negeri 9 Kota Jambi is 4.15 with Respondent Achievement Level (TCR) of 82.93. This suggests that learning style variables fall into either category. From 3 (three) indicator of studied learning style, it is known that (1) visual indicator get average, that is 4,22 with TCR equal to 84,47, so that in good category, (2) kinesthetic indicator get average 4 , 18 with TCR of 83.58, so it is in good category, and (3) the auditorial indicator obtains the average, that is 4.04 with TCR of 80.74 , so it is in good category.
\end{abstract}

Keywords: Analysis, Learning Styles, IPS Subject

\section{PENDAHULUAN}

Pendidikan adalah media mencerdaskan kehidupan bangsa dan membawa suatu bangsa pada era aufklarung (pencerahan). Pendidikan bertujuan untuk membangun tatanan suatu bangsa yang berbalut dengan nilai-nilai kepintaran, kepekaaan, dan kepedulian terhadap kehidupan berbangsa dan bernegara. Pendidikan merupakan tonggak kuat untuk mengentaskan kemiskinan pengetahuan, menyelesaikan persoalan kebodohan, dan menuntaskan segala permasalahan bangsa. Peran pendidikan jelas merupakan hal yang signifikan dan sentral karena pendidikan memberikan pembukaan dan perluasan pengetahuan, sehingga suatu bangsa betul-betul melek terhadap kehidupan berbangsa dan bernegara. Pendidikan dihadirkan untuk mengantarkan suatu bangsa menjadi bangsa yang beradab dan berbudaya. Pendidikan dilahirkan untuk memperbaiki segala kebobrokan yang sudah menggumpal di segala sendi kehidupan bangsa.

Pendidikan merupakan satu-satunya aset untuk membangun Sumber Daya Manusia (SDM) yang berkualitas, yang mampu bersaing secara kompetitif di era persaingan yang semakin ketat dalam berbagai aktivitas kehidupan. SDM yang berkualitas memegang peranan yang sangat penting dalam menentukan keberhasilan berbagai sektor pembangunan suatu bangsa, baik fisik maupun non fisik. SDM yang berkualitas ini salah satunya dapat diciptakan melalui lembaga pendidikan sekolah sebagai penyelenggara pendidikan formal. Sekolah mendapatkan kepercayaan dari masyarakat dalam mempersiapkan dan mengantarkan generasi penerus bangsa untuk mampu bersaing dalam kompetisi global yang semakin hari semakin terasa dampaknya terhadap berbagai aktivitas kehidupan bermasyarakat.

Penyelenggaraan pendidikan di sekolah harus mampu menumbuhkan berbagai kompetensi peserta didik. Keterampilan intelektual, sosial, dan personal dibangun tidak hanya dengan landasan rasio dan logika saja, tetapi juga inspirasi, kreativitas, moral, emosi, dan spiritual. Oleh karena itu, sekolah sebagai institusi pendidikan dan miniatur masyarakat perlu mengembangkan pembelajaran sesuai dengan tuntutan kebutuhan era globalisasi. Hal ini dikarenakan pembelajaran merupakan suatu sistem yang memiliki peran sangat dominan untuk mewujudkan kualitas pendidikan.

Sekolah Menengah Pertama (SMP) merupakan salah satu bentuk satuan pendidikan formal yang menyelenggarakan pendidikan pada jenjang pendidikan dasar. Peraturan Pemerintah No. 17 Tahun 2010 tentang Pengelolaan dan Penyelenggaraan Pendidikan, pasal 1 ayat (10) mengatakan bahwa "Sekolah Menengah Pertama yang selanjutnya disingkat SMP, adalah salah satu bentuk satuan pendidikan formal yang menyelenggarakan pendidikan umum pada jenjang pendidikan dasar sebagai lanjutan dari SD, MI, atau bentuk lain yang sederajat atau lanjutan dari hasil belajar yang diakui sama atau setara SD atau Ml". Selanjutnya, pasal 67 ayat (2) mengemukakan bahwa pendidikan pada SMP/MTs atau bentuk lain yang sederajat memiliki fungsi sebagai berikut:

1. Mengembangkan, menghayati, dan mengamalkan nilai-nilai keimanan, akhlak mulia, dan kepribadian luhur yang telah dikenalinya.

2. Mengembangkan, menghayati, dan mengamalkan nilai-nilai kebangsaan dan cinta tanah air yang telah dikenalinya.

3. Mempelajari dasar-dasar ilmu pengetahuan dan teknologi.

4. Melatih dan mengembangkan kepekaan dan kemampuan mengapresiasi serta mengekspresikan keindahan, kehalusan, dan harmoni.

5. Mengembangkan bakat dan kemampuan di bidang olahraga, baik untuk kesehatan dan kebugaran jasmani maupun prestasi.

6. Mengembangkan kesiapan fisik dan mental untuk melanjutkan pendidikan ke jenjang pendidikan menengah dan/atau untuk hidup mandiri di masyarakat.

Tercapai atau tidaknya fungsi pendidikan di atas tidak terlepas dari interaksi antara peserta didik dengan 
pendidik dan sumber belajar pada suatu lingkungan belajar.

Mata pelajaran IImu Pengetahuan Sosial (IPS) merupakan salah satu mata pelajaran yang disajikan pada satuan pendidikan SMP termasuk di SMP Negeri 9 Kota Jambi. Mata pelajaran IPS pada satuan pendidikan SMP meliputi mata pelajaran Ekonomi, Sejarah, dan Geografi. Pada hakekatnya, tujuan mata pelajaran IPS pada satuan pendidikan SMP adalah (1) mengenal konsep-konsep yang berkaitan dengan kehidupan masyarakat dan lingkungannya, (2) memiliki kemampuan dasar untuk berpikir logis dan kritis, rasa ingin tahu, inkuiri, memecahkan masalah, dan keterampilan dalam kehidupan sosial, (3) memiliki komitmen dan kesadaran terhadap nilai-nilai sosial dan kemanusiaan, dan (4) memiliki kemampuan berkomunikasi, bekerjasama dan berkompetisi dalam masyarakat yang majemuk, di tingkat lokal, nasional, dan global.

Keberhasilan proses pembelajaran peserta didik, tidak terkecuali pada mata pelajaran IPS salah satunya tercermin dari hasil belajar yang diperoleh peserta didik, yang dipengaruhi oleh beberapa faktor. Faktor-faktor yang mempengaruhi hasil belajar peserta didik dapat diklasifikasikan menjadi 2 (dua), yaitu faktor intern (berasal dari dalam diri peserta didik) dan faktor ekstern (berasal dari luar diri peserta didik). Salah satu faktor intern yang mempengaruhi hasil belajar peserta didik adalah gaya belajar. Menurut Nasution (2008:93) "Gaya belajar adalah cara siswa bereaksi dan menggunakan perangsang-perangsang yang diterimanya dalam proses belajar".

Berdasarkan observasi yang penulis laksanakan di kelas VII SMP Negeri 9 Kota Jambi diketahui bahwa masih ada guru yang tidak memahami gaya belajar yang dimiliki oleh setiap peserta didik, sehingga proses pembelajaran kurang efektif dan efisien. Selain itu, masih ada peserta didik yang belum mampu memaksimalkan gaya belajarnya karena mereka belum menyadari gaya belajar yang mereka miliki, sehingga berpengaruh terhadap hasil belajar yang mereka peroleh.

Adapun tujuan penelitian ini adalah untuk menganalisis gaya belajar siswa pada mata pelajaran IPS di kelas VII SMP Negeri 9 Kota Jambi.

\section{METODE PENELITIAN}

Penelitian yang peneliti laksanakan ini termasuk jenis penelitian deskriptif dengan pendekatan kuantitatif. Menurut Darmadi (2011:19) "Penelitian deskriptif adalah penelitian yang dilakukan pada variabel-variabel yang diteliti akan menjelaskan objek yang diteliti melalui data yang terkumpul". Penelitian ini melihat bagaimana gaya belajar siswa pada mata pelajaran IPS di kelas VII SMP Negeri 9 Kota Jambi. Adapun populasi penelitian ini adalah siswa kelas VII di SMP Negeri 9 Kota Jambi, yang berjumlah 251 orang siswa. Teknik pengambilan sampel pada penelitian ini adalah proportional random sampling, sehingga terpilih 72 orang siswa sebagai sampel penelitian.

Teknik pengumpulan data pada penelitian ini adalah angket (Questionnaire). Riduwan (2009:71) mengemukakan bahwa "Angket adalah daftar pertanyaan yang diberikan kepada orang lain yang bersedia memberikan respons (responden) sesuai dengan permintaan pengguna". Angket penelitian ini diberikan kepada siswa kelas VII di SMP Negeri 9 Kota Jambi. Angket penelitian ini berbentuk angket tertutup. Angket penelitian ini disusun berdasarkan skala Likert. Sugiyono (2013:93) mengemukakan bahwa "Skala Likert adalah skala yang digunakan untuk mengukur sikap, pendapat, dan persepsi seseorang atau sekelompok orang tentang fenomena sosial". Skala Likert yang digunakan dalam penelitian ini terdiri atas 5 (lima) alternatif jawaban.

Teknis analisis data pada penelitian ini adalah analisis deskripif. Analisis deskriptif bertujuan untuk memberikan gambaran umum tentang variabel yang diteliti dengan cara menyajikan data ke dalam tabel distribusi frekuensi. Adapun variabel penelitian yang dideskripsikan adalah gaya belajar. Setelah data disajikan ke dalam tabel distribusi frekuensi maka dilakukan analisis persentase dan interpretasi terhadap hasil analisis.

\section{HASIL PENELITIAN}

Variabel gaya belajar diukur dengan menggunakan skala likert. Berdasarkan jumlah item pertanyaan variabel gaya belajar (30 item), maka skor minimum variabel gaya belajar adalah 30 dan skor maksimumnya adalah 150. Hasil analisis frekuensi variabel gaya belajar yang diteliti terdapat pada lampiran 7 yang kesimpulannya dapat dilihat pada tabel 9 . Berdasarkan hasil analisis tersebut dapat disimpulkan bahwa rata-rata variabel gaya belajar adalah 4,15 dengan Tingkat Capaian Responden (TCR) sebesar 82,93. Artinya, variabel gaya belajar berada pada kategori baik. Adapun deskripsi masing-masing indikator variabel gaya belajar berdasarkan TCR dapat dilihat pada tabel sebagai berikut:

Tabel 1. Analisis Frekuensi Variabel Gaya Belajar

\begin{tabular}{|c|c|c|c|c|}
\hline No. & Pernyataan & Rata-rata & TCR & Kategori \\
\hline A. & Auditorial & & & \\
\hline 1. & $\begin{array}{l}\text { Saya lebih mudah mengingat materi pelajaran yang disampaikan } \\
\text { secara lisan oleh guru }\end{array}$ & 3.64 & 72.78 & Cukup \\
\hline 2. & Saya mengeluarkan suara ketika membaca buku & 4.00 & 80.00 & Baik \\
\hline 3. & Saya lebih suka berdiskusi daripada membaca & 4.21 & 84.17 & Baik \\
\hline 4. & $\begin{array}{l}\text { Saya merasa kesulitan untuk menuliskan kembali materi pelajaran } \\
\text { yang disampaikan oleh guru }\end{array}$ & 3.25 & 65.00 & Cukup \\
\hline 5. & $\begin{array}{l}\text { Saya mudah terganggu dengan suara / bunyi-bunyian ketika } \\
\text { sedang belajar }\end{array}$ & 4.50 & 90.00 & Sangat Baik \\
\hline 6. & Saya senang bersenandung pada saat mengerjakan tugas & 4.18 & 83.61 & Baik \\
\hline 7. & Pada saat diskusi saya menanggapi jawaban dari teman & 4.13 & 82.50 & Baik \\
\hline 8. & Saya menyukai musik bernada irama & 4.28 & 85.56 & Baik \\
\hline 9. & Saya lebih mudah menunjukkan letak dengan menggunakan & 4.15 & 83.06 & Baik \\
\hline
\end{tabular}


bahasa daripada tulisan

\begin{tabular}{|c|c|}
\hline \multicolumn{2}{|r|}{ Rata-rata Indikator I } \\
\hline B. & Visual \\
\hline 10. & Saya malas menjawab pertanyaan yang diberikan oleh guru \\
\hline 11. & Saya tidak mudah terganggu keributan ketika sedang belajar \\
\hline 12. & Saya menjawab pertanyaan yang diberikan oleh guru secara singkat \\
\hline 13. & Saya lebih suka membaca daripada dibacakan \\
\hline 14. & Saya membaca buku dengan cepat \\
\hline 15. & $\begin{array}{l}\text { Saya lebih mudah memahami materi pelajaran ketika guru mengajar } \\
\text { menggunakan media pelajaran }\end{array}$ \\
\hline 16. & Saya mempunyai catatan mata pelajaran IPS yang lengkap dan rapi \\
\hline 17. & $\begin{array}{l}\text { Ketika mengerjakan tugas, saya selalu membaca intruksi atau } \\
\text { perintahnya terlebih dahulu }\end{array}$ \\
\hline 18. & $\begin{array}{l}\text { Saya senang menggunakan stabilo untuk memperjelas tulisan- } \\
\text { tulisan dalam catatan }\end{array}$ \\
\hline 19. & Saya mempunyai jadwal belajar yang teratur \\
\hline 20. & Setelah belajar, saya merapikan kembali buku dan alat tulis \\
\hline 21. & Saya menggunakan jari untuk menunjuk kalimat yang dibaca \\
\hline \multicolumn{2}{|r|}{ Rata-rata Indikator II } \\
\hline C. & Kinestetik \\
\hline 22. & Saya sulit duduk diam dalam jangka waktu yang lama ketika belajar \\
\hline 23. & Saya menyukai mata pelajaran yang bersifat praktek \\
\hline 24. & Saya mencoret-coret kertas ketika belajar \\
\hline 25. & Saya lebih cepat menghafal materi pelajaran sambil berjalan \\
\hline 26. & $\begin{array}{l}\text { Ketika menyampaikan pendapat/ menjawab pertanyaan, saya } \\
\text { berbicara dengan lambat dan pelan }\end{array}$ \\
\hline 27. & $\begin{array}{l}\text { Pada saat guru menerangkan materi pelajaran, tangan saya tidak } \\
\text { bisa diam memainkan pena/benda lainnya yang ada di dekat saya }\end{array}$ \\
\hline 28. & $\begin{array}{l}\text { Ketika menjelaskan materi pelajan kepada teman, saya menyentuh } \\
\text { teman tersebut untuk memperoleh perhatiannya }\end{array}$ \\
\hline 29. & Saya menyentuh orang untuk mendapatkan sesuatu \\
\hline 30. & $\begin{array}{l}\text { Saya berdiri sangat dekat ketika berbicara dengan orang yang } \\
\text { sedang saya ajak berbicara }\end{array}$ \\
\hline & $\begin{array}{c}\text { Rata-rata Indikator III } \\
\text { Rata-rata Variabel Gaya Belajar }\end{array}$ \\
\hline
\end{tabular}

$\begin{array}{lll}4.04 & 80.74 & \text { Baik } \\ 4.10 & 81.94 & \text { Baik } \\ 4.15 & 83.06 & \text { Baik } \\ 3.99 & 79.72 & \text { Baik } \\ 4.40 & 88.06 & \text { Baik } \\ 4.04 & 80.83 & \text { Baik } \\ 4.17 & 83.33 & \text { Baik } \\ 4.38 & 87.50 & \text { Baik } \\ 4.28 & 85.56 & \text { Baik } \\ 4.17 & 83.33 & \\ 4.22 & 84.44 & \text { Baik } \\ 4.39 & 87.78 & \text { Baik } \\ 4.40 & 88.06 & \text { Baik } \\ 4.22 & 84.47 & \text { Baik } \\ & & \text { Baik } \\ 4.19 & 83.89 & \\ 4.24 & 84.72 & \text { Baik } \\ 4.17 & 83.33 & \text { Baik } \\ 4.31 & 86.11 & \text { Baik } \\ 3.92 & 78.33 & \text { Baik } \\ & & \text { Cukup } \\ 4.11 & 82.22 & \\ 4.15 & 83.06 & \text { Baik } \\ 4.40 & 88.06 & \text { Baik } \\ 4.13 & 82.50 & \text { Baik } \\ 4.18 & 83.58 & \text { Baik } \\ 4.15 & 82.93 & \text { Baik } \\ & & \\ & & \text { Baik }\end{array}$

Berdasarkan tabel 1 di atas diperoleh informasi bahwa indikator auditorial memperoleh rata-rata 4,04 dengan TCR sebesar 80,74. Hal ini berarti bahwa indikator auditorial termasuk pada kategori baik. Dari 9 (sembilan) item pernyataan, pernyataan saya mudah terganggu dengan suara atau bunyi-bunyian ketika sedang belajar memperoleh rata-rata tertinggi, yaitu 4,50 dengan TCR sebesar 90,00, sehingga berada pada kategori sangat baik. Hal ini dibuktikan dengan 43 orang siswa $(59,72 \%)$ yang menjawab selalu, 22 orang siswa $(30,56 \%)$ yang menjawab sering, dan 7 orang siswa $(9,72 \%)$ yang menjawab kadang-kadang. Sedangkan, pernyataan saya merasa kesulitan untuk menuliskan kembali materi pelajaran yang disampaikan oleh guru memperoleh rata-rata terendah, yaitu 3,25 dengan TCR sebesar 65,00 , sehingga berada pada kategori cukup. Hal ini dibuktikan dengan 4 orang siswa $(5,56 \%)$ yang menjawab selalu, 10 orang siswa $(13,89 \%)$ yang menjawab sering, dan 58 orang siswa $(80,56 \%)$ yang menjawab kadang-kadang.

Indikator visual memperoleh rata-rata 4,42 dengan TCR sebesar 84,47. Hal ini berarti bahwa indikator visual berada pada kategori baik. Dari 12 (dua belas) item pernyataan, saya lebih suka membaca daripada dibacakan memperoleh rata-rata tertinggi, yaitu 4,40 dengan TCR sebesar 88,06, sehingga termasuk pada kategori baik. Hal ini dibuktikan dengan 42 orang siswa $(58,33 \%)$ yang menjawab selalu, 17 orang siswa $(23,61 \%)$ yang menjawab sering, dan 13 orang siswa $(18,06 \%)$ yang menjawab kadang-kadang. Selain itu, pernyataan saya menggunakan jari untuk menunjuk kalimat yang dibaca juga memperoleh rata-rata tertinggi, yaitu 4,40 dengan TCR sebesar 88,06, sehingga berada pada kategori baik. Hal ini dibuktikan dengan 42 orang siswa $(58,33 \%)$ yang menjawab selalu, 17 orang siswa $(23,61 \%)$ yang menjawab sering, dan 13 orang siswa $(18,06 \%)$ yang menjawab kadang-kadang. Sedangkan, pernyataan saya menjawab pertanyaan yang diberikan oleh guru secara singkat memperoleh rata-rata terendah, yaitu 3,99 dengan TCR sebesar 79,72, sehingga berada pada kategori baik. Hal ini dibuktikan dengan 21 orang siswa $(29,17 \%)$ yang menjawab selalu, 29 orang siswa $(40,28 \%)$ yang menjawab sering, dan 22 orang siswa $(30,56 \%)$ yang menjawab kadang-kadang.

Indikator kinestetik memperoleh rata-rata 4,18 dengan TCR sebesar 83,58. Hal ini menunjukkan bahwa indikator kinestetik berada pada kategori baik. Dari 9 (sembilan) item pernyataan, pernyataan saya menyentuh orang untuk mendapatkan sesuatu memperoleh rata-rata tertinggi, yaitu 4,40 dengan TCR sebesar 88,06, sehingga berada pada kategori baik. Hal ini dibuktikan dengan 42 orang siswa $(58,33 \%)$ yang menjawab selalu, 17 orang siswa $(23,61 \%)$ yang menjawab sering, dan 13 orang siswa $(18,06 \%)$ yang menjawab kadang-kadang. Sedangkan, pernyataan ketika menyampaikan pendapat atau menjawab pertanyaan saya berbicara dengan lambat dan pelan memperoleh rata-rata terendah, yaitu 3,92 dengan TCR sebesar 78,33, sehingga berada pada kategori cukup. Hal ini dibuktikan dengan 14 orang siswa $(19,44 \%)$ yang menjawab selalu, 38 orang siswa $(52,78 \%)$ yang menjawab sering, dan 20 orang siswa $(27,78 \%)$ yang menjawab kadang-kadang.

\section{Pembahasan}

Berdasarkan deskripsi variabel gaya belajar diketahui bahwa rata-rata variabel gaya belajar siswa pada mata pelajaran IPS di kelas VII SMP Negeri 9 Kota 
Jambi adalah 4,15 dengan Tingkat Capaian Responden (TCR) sebesar 82,93. Hal ini menunjukkan bahwa variabel gaya belajar termasuk pada kategori baik. Dari 3 (tiga) indikator variabel gaya belajar yang diteliti diketahui bahwa indikator visual memperoleh rata-rata yang paling tinggi, yaitu 4,22 dengan TCR sebesar 84,47 , sehingga termasuk pada kategori baik. Sedangkan, indikator kinestetik memperoleh rata-rata 4,18 dengan TCR sebesar 83,58, sehingga termasuk pada kategori baik. Selanjutnya, indikator auditorial memperoleh rata-rata terendah, yaitu 4,04 dengan TCR sebesar 80,74, sehingga berada pada kategori baik.

Hasil temuan peneliti ini menunjukkan bahwa gaya belajar siswa pada mata pelajaran IPS di kelas VII SMP Negeri 9 Kota Jambi didominasi oleh gaya belajar visual. Hal ini diperkuat oleh hasil penelitian Fidhiyanti (2016:1) yang menemukan bahwa gaya belajar siswa kelas X Akuntansi 1 di SMK Negeri 3 Pontianak paling didominasi oleh gaya belajar visual, yaitu sebanyak 24 orang siswa $(60 \%)$.

\section{SIMPULAN}

Berdasarkan hasil penelitian yang peneliti peroleh, maka dapat diambil kesimpulan bahwa rata-rata variabel gaya belajar siswa pada mata pelajaran IPS di kelas VII SMP Negeri 9 Kota Jambi adalah 4,15 dengan Tingkat Capaian Responden (TCR) sebesar 82,93. Hal ini menunjukkan bahwa variabel gaya belajar termasuk pada kategori baik. Dari 3 (tiga) indikator variabel gaya belajar yang diteliti diketahui bahwa:

1. Indikator visual memperoleh rata-rata, yaitu 4,22 dengan TCR sebesar 84,47 , sehingga berada pada kategori baik.

2. Indikator kinestetik memperoleh rata-rata 4,18 dengan TCR sebesar 83,58, sehingga berada pada kategori baik.

3. Indikator auditorial memperoleh rata-rata, yaitu 4,04 dengan TCR sebesar 80,74, sehingga berada pada kategori baik.

\section{DAFTAR PUSTAKA}

Darmadi, Hamid. 2011. Metode Penelitian Pendidikan. Bandung: Alfabeta.

Fidhiyanti, Auliya. 2016. "Analisis Gaya Belajar Siswa Kelas X Akuntansi 1 SMK Negeri 3 Pontianak". Jurnal Pendidikan dan Pembelajaran, Vol. 5, No. $11,13$.

Nasution, S. 2008. Berbagai Pendekatan Dalam Proses Belajar dan Mengajar. Jakarta: PT. Bumi Aksara.

Riduwan. 2009. Belajar Mudah Penelitian Untuk GuruKaryawan dan Peneliti Pemula. Bandung: Alfabeta.

Sugiyono. 2013. Metode Penelitian Kuantitatif, Kualitatif, dan R\&D. Bandung: Alfabeta.

Peraturan Pemerintah No. 17 Tahun 2010. 